\title{
Special Issue of Scientia et Fides on Experimental Psychology and the Notion of Personhood
}

\author{
JUAN F. FRANCK
}

Universidad Austral, Argentina

jfranck@austral.edu.ar

ORCID: 0000-0002-7480-0188

\section{SCOTT HARROWER}

Ridley College Melbourne, Australia

harrower.scott@gmail.com

ORCID: 0000-0002-0729-7092

\section{RYAN PETERSON}

Talbot School of Theology, Biola University, United States ryan.peterson@biola.edu

ORCID: 0000-0003-1086-4147

Close interaction between psychology and philosophy is certainly not a novelty, since the various schools - associationism, psychoanalysis, behaviorism, etc. - were born with strong philosophical assumptions. With the gradual but consistent introduction of scientific methods, psychology became more and more independent and rightfully claimed a place among the human sciences. The $20^{\text {th }}$ century has seen incredibly rap- 
id growth in branches of psychology - e.g., cognitive, social, personality, moral, developmental, evolutionary, and cultural psychology- to the point that it has become impossible for any single scholar to have an encompassing picture of the whole field, mirroring what happens in other sciences as well, such as physics, biology and sociology. Far from discouraging, the situation rather speaks of the fruitfulness of psychology and of its potential to engage in serious dialogue with other disciplines, insofar they share a common interest.

More recently, cognitive psychologists have used the resources of psychological science to study the foundations of religion, and to discuss and possibly illuminate issues of concern for theologians. The new field, known as the cognitive science of religion (CSR), draws from work by Ernest Thomas Lawson, Robert McCauley, Pascal Boyer and Justin Barrett, among others. Many of its scholars are inspired by a spirit of collaborative work with theologians and philosophers of religion, emphasizing the need of serious cross-training between disciplines. Driven by the same spirit, the present issue of Scientia et Fides documents instances of integrative work at the intersection of psychological science and philosophical or theological knowledge, specifically centered around our understanding of what a person is. We hope that, apart from their individual worth, as a whole these contributions will stimulate further interdisciplinary studies, in order to achieve genuine science-engaged philosophy and theology, and a science that is aware of philosophical and theological discussions.

We have deliberately not chosen one specific notion or definition of personhood to serve as a guide, in order to allow for different but not necessarily rivalling conceptions. Still, it seems safe to claim that a correct understanding of persons - be it in the form of a definition proper or as a description- should accommodate all dimensions of our human experience: embodiment, subjectivity, interiority, relationality, spirituality, morality and transcendence, and that all these dimensions fall within the study field of both science and philosophy/theology.

The first two papers deal with the general conceptual framework that is necessary for a fruitful interaction to take place. Erin I. Smith discusses 
the differences emerging from psychological and neuroscientific research on the self, which impact on our understanding of persons. Whereas developmental psychology highlights the role of intuitive beliefs in individuals' stable sense of self, neuroscientific studies seem to uncover a multitude of de-centralized neural networks in competition as responsible for individuals' sense of self. Smith explores how to bring together these divergent empirical views to advance understanding about personhood, as well as how philosophy and theology can inform scientific research on the self. Drawing from philosophical considerations, Juan F. Franck proposes that the rich variety of methods in psychological research used to study human subjectivity could find a robust and also flexible conceptual framework in the phenomenological understanding of the person. The one using empirical methods, the other seeking the foundations of experience, psychology and phenomenology both converge in disclosing the person-centeredness of our lifeworld, which is impregnated by all our vital, cultural, ethical, social and religious interests.

The idea that philosophical claims underlie widespread cultural tenets, whether we are aware of them or not, is well documented in Juan Pablo Roldán’s article. A tacit “philosophical dogma” would be present in many cultural trends, both philosophical and psychological, namely that a substantive conception of the person stands in the way of interpersonal communion. Roldán claims that sharing and communicating is at the operative level, whereas individuality qualifies the person ontologically. Far from being an obstacle, a robust sense of being an individual self, would be a condition for true sharing. The tacit assumption of a dualist stance supporting a robust self has often resulted in a problematic understanding of persons, compromising them as truly relational individuals.

Scott Harrower's and Kyle Strobel's papers exploit the resources of psychology for theological investigation, which in turn raises new questions for psychological research. Harrower argues that proponents of using a person as an analogy for the Godhead will be better served by using a psychologically informed analogy of a "self" instead. He argues that the "Dialogical Self Analogy" for the Godhead is more likely to uphold God's trinitarian nature, avoid trinitarian confusion and related problems than 
"person" analogies do. On this view, the primary benefit of speaking of God as a Dialogical Self is that it offers a psychologically modelled analogy for God, whilst avoiding the language of person, yet strongly taking into account God's trinitarian nature. This has the important benefit of preserving the concept and language of "person" for the trinitarian persons (the prosopa/hypostases), and hence avoiding the linguistic, conceptual and ecumenical confusion that arises when referring to the Godhead as a person.

Strobel addresses gratitude as an element of human flourishing. He does so by analyzing $18^{\text {th }}$ century theologian Jonathan Edwards's distinction between natural and supernatural gratitude to God, together with its implications for psychology. A Christian account of gratitude has to contemplate both forms. The opening or enlargement of the self to another mirrors God's self-giving and is a response based on God's action in the soul, going thus beyond the possibilities of human nature alone. The consideration of the two forms of gratitude also sheds light on the impact gratitude has on human wellbeing, on our attitude towards oneself and others. There is here abundant work to be done.

Taking recourse to recent empirical studies in social and cognitive psychology Natasza Szutta defends the classical notion of virtue against the critiques of situationists. The author claims that contrary to what situationists think, there is empirical evidence that moral character warrants a morally good action and does not go against the necessary flexibility that human situations require from the moral agent. Virtue is not classically understood as a repetition of identical or similar acts, but rests on the dynamic and flexible development of an ability rooted on human experience and action. At any rate a strong moral character seems to be a firm condition for upright behavior.

José Víctor Orón Semper and Miriam Martínez Mares argue against a fragmented understanding of human reality and propose instead an integral approach to human action, relying on psychological, theological and philosophical considerations. They introduce interiority as a necessary element to account for the person's complexity, which they see reflected in several interacting levels. Not everything is amenable to a fixed 
conceptualization, however, and a realistic and open-minded understanding of the person must acknowledge that there always remains in her something unfathomable and mysterious.

Claudia E. Vanney and Ignacio Aguinalde suggest that the excess of specialization in contemporary research can be overcome by means of a collaborative process of social cognition. To illustrate the dynamics of a successful interdisciplinary research team they propose an extension of the psychological notion of joint attention towards what they call joint intellectual attention. This kind of joint attention involves a shared awareness of sharing the cognitive process of knowledge, and therefore requires specific intellectual dispositions and virtues from team members. It appears that not only focusing on a common object is a condition for effective interdisciplinarity, but also establishing some kind of secondperson relatedness. 